\title{
Autotrophic Denitrification for Nitrate Removal from Groundwater with an Integrated Microbial Fuel Cells (MFCs)- microbial Electrolysis Cell (MEC) System
}

\author{
Chengye Wang ${ }^{1}$, Yue $W u^{2}$, Wei $H u^{1}$, Yan $\mathrm{Li}^{1,2,3, *}$ \\ ${ }^{1}$ College of New Energy and Environment, Jilin University, Changchun 130021, China. \\ ${ }^{2}$ Key Laboratory of Groundwater Resources and Environment (Jilin University), Ministry of Education, \\ Changchun 130021, China. \\ ${ }^{3}$ National and Local Joint Engineering Laboratory for Petrochemical Contaminated Site Control and \\ Remediation Technology, Changchun 130021, China. \\ *E-mail: yli8299@163.com
}

doi: $10.20964 / 2021.01 .10$

Received: 2 September 2020 / Accepted: 25 October 2020 / Published: 30 November 2020

\begin{abstract}
Bioelectrochemical system (BES) that is self-sufficient was developed to treat nitrate in groundwater, which consists of air cathode microbial fuel cell (MFC) and microbial electrolysis cell (MEC). Without external power, the highest nitrate removal rate and the highest removal efficiency of autotrophic denitrification MFC were $10.6 \mathrm{mg} /(\mathrm{L} \cdot \mathrm{d})$ and $56.5 \%$, respectively. However, the highest denitrification rate increased to $13.5 \mathrm{mg} /(\mathrm{L} \cdot \mathrm{d})$ when three air cathode MFCs $(0.8 \mathrm{~V})$ were adopted in series as the power source for autotrophic denitrification MEC, which was $27.4 \%$ higher than that of autotrophic denitrification MFC. In addition, the nitrate removal efficiency was as high as $80.6 \%$, which was the same to that of the conventional biological nitrogen removal (BNR). Thereby, autotrophic denitrification was significantly improved in MFCs-MEC and the hybrid system made BES more feasible in treating low ionic strength water $(<1000 \mu \mathrm{S} / \mathrm{cm})$ like groundwater. Furthermore, excessive organic input to groundwater was avoided by the autotrophic denitrification which might cause secondary pollution to it.
\end{abstract}

Keywords: nitrate removal; autotrophic denitrification; groundwater pollution; microbial electrolysis cell; microbial fuel cell

\section{FULL TEXT}

(C) 2021 The Authors. Published by ESG (www.electrochemsci.org). This article is an open access article distributed under the terms and conditions of the Creative Commons Attribution license (http://creativecommons.org/licenses/by/4.0/). 